\title{
Kajian Analisis Kebutuhan Air Bersih \\ Bagi Warga Masyarakat dan Perusahaan \\ (Studi Pada Kecamatan Ciampel, Kecamatan Klari dan Kecamatan Purwarasi)
}

\author{
Oleh : Puji Isyanto ${ }^{1}$, Dedi Mulyadi ${ }^{2}$ \\ Email : ${ }^{1}$ puji.isyanto@ubpkarawang.ac.id, ${ }^{2}$ dedi.mulyadi@ubpkarawang.ac.id
}

\begin{abstract}
Abstrak
Tujuan penelitian ini untuk menganalisis kebutuhan air bersih bagi masyarakat dan perusahaan. Manfaat penelitian diharapkan dapat menjadi bahan masukan dan rekomendasi terhadap penyediaan kebutuhan air bersih dan meningkatkan pelayanan kepada masyarakat.

Penelitian ini merupakan jenis penelitian survei yang mengambil sampel warga masyarakat yang dilaksanakan dengan cara mengambil sampel dari satu populasi dan menggunakan kuesioner sebagai alat pengumpulan data pokok. Penelitian ini terlebih dahulu dilakukan identifikasi karakteristik masyarakat, identifikasi persepsi pengguna terhadap penyediaan air bersih kemudian dilanjutkan identifikasi aspek-aspek yang mempengaruhi penyediaan air bersih berdasar aspek-aspek yang berhubungan.

Hasil penelitian ini secara keseluruhan dilihat dari berbagai aspek, penyediaan air bersih pada saat ini, belum cukup memenuhi kebutuhan secara optimal. Dengan demikian penyediaan air bersih melalui perusahaan lain selain Perusahaan Daerah Air Minum (PDAM) dapat menjadi salah satu alternatif untuk memenuhi kebutuhan air bersih. Semakin padatnya warga masyarakat dan perusahaan/industri, maka akan dihadapkan pada masalah penyediaan air bersih yang semakin besar. Sarana air bersih yang minim dengan sumber daya air yang semakin terbatas menjadi satu kendala yang sangat berarti. Semakin bertambah jumlah warga masyarakat dan perusahaan/industri maka akan semakin bertambah banyak sehingga kebutuhan air bersih juga semakin bertambah. Dengan demikian penyediaan air bersih dari sumber-sumber lain juga sangat diperlukan.
\end{abstract}

Kata kunci : kebutuhan, air bersih, masyarakat, perusahaan.

\section{Latar Belakang}

Sistem penyediaan kebutuhan air bersih merupakan salah satu komponen prasarana kota. Prasarana berperan sangat penting bagi pertumbuhan dan perkembangan suatu kota, karena prasarana dapat memberi dampak terhadap peningkatan taraf dan mutu kehidupan masyarakat, pola pertumbuhan dan prospek perkembangan ekonominya. Air bersih merupakan salah satu hal yang penting dan mendapat prioritas dalam perencanaan kota.

Tanggungjawab penyediaan prasarana dan pelayanan perkotaan ditanggung bersama oleh pemerintah pusat dan daerah berdasarkan prinsip dekonsentrasi, desentralisasi dan pembantuan. Penyediaan air bersih pada prinsipnya diutamakan bagi masyarakat yang belum memiliki akses terhadap air bersih. (Kodoatie, 2003:151-152). Melalui regulasi Pemerintah diatur kesempatan peran serta masyarakat dan dunia usaha termasuk untuk kegiatan yang penting bagi negara dan menguasai hajat hidup orang banyak, diantaranya dalam penyediaan air bersih (Kodoatie et.al., 2002:59).

Permasalahan ketersediaan air bersih/air minum merupakan salah satu masalah utama perkotaan. Ketersediaan air bersih untuk perkotaan ini terkait erat dengan permasalahan pemanfaatan, pemeliharaan dan kelestarian sumber daya air yang pada umumnya berada di wilayah sekitarnya (Tjahjati et.al., 2005:8). Menurut wawancara, PDAM dengan keterbatasan yang ada, sebenarnya bersedia untuk menyediakan air bersih di beberapa wilayah yang belum tersedia jaringan, namun sampai saat ini terkendala oleh terbatasnya 
jaringan serta belum adanya masyarakat yang mengajukan langganan air bersih dengan PDAM. Keterbatasan PDAM tersebut tidak terlepas dari berbagai aspek yang mempengaruhi, diantaranya aspek teknik operasional, aspek kelembagaan, aspek pembiayaan dan aspek peran serta masyarakat.

Kondisi keterbatasan PDAM hampir sama dialami oleh PDAM di kota- kota lain di Indonesia. Berdasarkan data, pada Aspek Teknik Operasional terlihat adanya permasalahan kekeringan sumber air setiap tahun terutama terjadi pada saat musim kemarau. Air baku merupakan masalah utama dalam penyediaan air bersih, karena cadangan air yang dimiliki selalu mengalami fluktuasi pada musim kemarau dan penghujan. Sumber daya air yang dapat dijadikan sumber air baku semakin terbatas. Pada umumnya sumber air baku yang ada tersebar, belum terukur dengan debit relatif kecil. Kualitas, kuantitas dan kontinuitas juga masih terbatas. Kemudian keterbatasan kapasitas pengelolaan pada IPA (Instalasi Pengolahan Air Minum, jangkauan jaringan yang terbatas, unit pengolah dan jaringan distribusi yang sudah tua, serta tingkat kebocoran jaringan air yang cukup tinggi.

Pada aspek kelembagaan menunjukkan belum adanya kemandirian dari PDAM karena campur tangan pemilik (Pemerintah Kabupaten) dalam manajemen pengelolaan, disamping itu sumber daya manusia (SDM) pengelola PDAM. Beberapa pelanggan menyampaikan bahwa seringkali PDAM mengabaikan pelayanan dan kepentingan pelanggan, keluhan pelanggan sering tidak ditanggapi dengan baik.

Pada aspek peran serta masyarakat menunjukkan bahwa peran serta masyarakat dalam penyelenggaraan penyediaan air minum masih terbatas. Peran masyarakat baru sebatas pengaduan bila terjadi kebocoran air maupun pelanggaran di lapangan. Peran masyarakat belum teridentifikasi pada peningkatan cakupan pelayanan, pengembangan maupun pengawasan air minum.

Untuk menjamin kesinambungan pasokan air bersih yang memenuhi syarat bagi kebutuhan penduduk kota, maka konsep penyediaan air harus merupakan bagian dari skenario pengelolaan kota. Ekosistem perkotaan merupakan ekosistem binaan yang memiliki keterbatasan daya dukung dan daya tampung lingkungan hidup, maka pilihan pendekatan pembangunan perkotaan akan sangat menentukan kualitas lingkungan perkotaan. Dewasa ini, konsep pembangunan berkelanjutan diusulkan sebagai upaya untuk mengkombinasikan kebutuhan mendesak akan pembangunan dan pentingnya menjaga lingkungan (Tjahjati et.al., 2005:375-401).

Pembangunan sarana dan prasarana air minum yang berkelanjutan (sustainable) memiliki makna bahwa pembangunan selain memenuhi kebutuhan saat ini juga tidak mengorbankan kemampuan untuk memenuhi kepentingan generasi yang akan datang (Bappenas, 2005:16).

\section{Permasalahan Penyediaan Air Bersih}

Kabupaten Karawang dikenal sebagai wilayah yang memiliki masalah dalam ketersediaan air, terutama pada saat musim kemarau. Hal ini dapat dilihat dari ketersediaan air, baik yang diusahakan oleh pemerintah melalui Perusahaan Daerah Air Minum (PDAM) maupun yang diusahakan oleh masyarakat sendiri yang belum dapat memenuhi kebutuhan dasar air di sepanjang tahun. Wilayah pelayanan PDAM yang belum merata, kapasitas pengelolaan yang belum sesuai kebutuhan, debit air baku yang tidak mencukupi, kontinuitas aliran yang tidak konsisten sampai kualitas air bersih yang belum sesuai standar merupakan masalah yang dihadapi saat ini.

Permasalahan yang ada dalam penyediaan air bersih di Kabupaten Karawang adalah : a. Belum meratanya pelayanan PDAM. 
Faktor utama belum meratanya pelayanan PDAM yang dapat dinikmati oleh masyarakat adalah keterbatasan kapasitas pengelolaan pada Instalasi Pengolah Air Minum (IPA) yang dimiliki. Pembangunan IPA baru membutuhkan invstasi yang cukup besar, disamping keterbatasan sumber air yang dijadikan sebagai sumber air baku. Jangkauan jaringan yang masih terbatas juga merupakan penyebab belum meratanya penyediaan air bersih terutama bagi daerah-daerah yang berjarak cukup jauh dari IPA.

b. Keterbatasan Sumber Air Baku

Keterbatasan air baku baik air permukaan maupun air tanah merupakan faktor penghambat bagi upaya-upaya peningkatan kapasitas instalasi pengolah air minum dan air irigasi. Kemungkinan penambahan IPA baru untuk memperluas wilayah pelayanan juga sangat bergantung pada jumlah air baku yang tersedia. Eksploitasi air tanah yang berlebihan juga merupakan faktor yang mempengaruhi berkurangnya cadangan air tanah yang dapat digunakan sebagai air baku (RPJM Kabupaten Karawang, 2006-2010:II-45).

Menurut Bappenas, 2005:17-18, sasaran kebijakan air minum dan penyehatan lingkungan antara lain :

1. Peningkatan akses, yaitu kesempatan, kemudahan dan kepuasan yang dimiliki oleh masyarakat untuk memperoleh pelayanan yang tersedia dalam penyediaan air minum dan penyehatan lingkungan.

2. Penggunaan efektif, yaitu sarana dan prasarana air minum dan penyehatan lingkungan yang dapat dimanfaatkan oleh masyarakat pengguna secara adil, tepat guna dan dengan cara yang sehat.

3. Keberlanjutan, yaitu sifat atau ciri terus menerus kegiatan untuk pemenuhan kebutuhan pengguna dengan mempertimbangkan aspek teknik, keuangan, sosial, kelembagaan dan lingkungan.

Kabupaten Karawang memiliki tiga sumber air yang cukup potensial dengan kualitas yang cukup baik untuk dikembangkan menjadi air minum kemasan. Ketiga sumber air dimaksud adalah :

1) Sumber air Ciburial dengan kapasitas 10 liter/detik, yang baru dimanfaatkan oleh PDAM Kabupaten Karawang 4 liter/detik, untuk melayani konsumen sebanyak 1.163 SL dan 27 KU tersebar di 4 desa.

2) Sumber air Curug Cigentis dengan kapasitas 300 liter/detik, dimanfaatkan untuk air minum pedesaan \pm 40 liter/detik guna melayani 4 desa.

3) Sumber air di Cinapel Desa Cigunungsari \pm 20 liter/detik, dimanfaatkan oleh masyarakat untuk kebutuhan pertanian.

Dari potensi air tersebut, baru dimanfaatkan untuk air minum pedesaan dan PDAM Kabupaten Karawang kurang lebih sebanyak 50 liter/ detik, sisanya 280 liter/detik belum dimanfaatkan, baik untuk kebutuhan air bersih maupun air kemasan lainnya.

Cakupan sarana air bersih, jamban keluarga dan TPM tahun 2012-2015 dapat ditunjukkan pada tabel di bawah ini.

Tabel 1

Cakupan Sarana Air Bersih Tahun 2012-2015

\begin{tabular}{|l|c|c|c|c|c|c|c|c|}
\hline \multirow{2}{*}{ Nama Sarana } & \multicolumn{2}{|c|}{2012} & \multicolumn{2}{c|}{2013} & \multicolumn{2}{c|}{2014} & \multicolumn{2}{c|}{2015} \\
\cline { 2 - 10 } & Jumlah & \% & Jumlah & \% & Jumlah & \% & Jumlah & \% \\
\hline Ledeng & 49.092 & 9,32 & 50.396 & 9,61 & 49.955 & 9,40 & 58.749 & 10,37 \\
\hline $\begin{array}{l}\text { Sumur Pompa } \\
\text { Tangan (SPT) }\end{array}$ & 86.891 & 16,49 & 76.897 & 14,67 & 74.957 & 14,10 & 70.834 & 12,51 \\
\hline
\end{tabular}


E ISSN : 2580-5517

\begin{tabular}{|l|c|c|c|c|c|c|c|c|}
\hline \multirow{2}{*}{ Nama Sarana } & \multicolumn{2}{|c|}{2012} & \multicolumn{2}{c|}{2013} & \multicolumn{2}{c|}{2014} & \multicolumn{2}{c|}{2015} \\
\cline { 2 - 10 } & Jumlah & \% & Jumlah & \% & Jumlah & \% & Jumlah & \% \\
\hline Sumur Gali (SGL) & 70.317 & 13,35 & 63.340 & 12,08 & 65.334 & 12,29 & 64.676 & 11,42 \\
\hline $\begin{array}{l}\text { Penampungan Mata } \\
\text { Air (PMA) }\end{array}$ & 2.069 & 0,39 & 2.069 & 0,39 & 2.337 & 0,44 & 2.337 & 0,41 \\
\hline $\begin{array}{l}\text { Penampungan Air } \\
\text { Hujan (PAH) }\end{array}$ & 1.566 & 0,3 & 1.554 & 0,30 & 1.488 & 0,28 & 1.534 & 0,27 \\
\hline Pompa Listrik & 224.309 & 42,57 & 238.535 & 45,50 & 245.474 & 46,18 & 274.094 & 75,88 \\
\hline
\end{tabular}

Sumber: Dinas Kesehatan Kabupaten Karawang

\section{Identifikasi Masalah}

Berdasarkan permasalahan-permasalahan yang telah diidentifikasi sebagai berikut :

1. Belum optimalnya pemerataan penyediaan air bersih bagi masyarakat

2. Keterbatasan cakupan pelayanan dari PDAM

3. Tingkat kebocoran air yang masih sangat tinggi

4. Banyaknya keluhan terhadap pelayanan PDAM

5. Belum optimalnya ketersediaan sarana dan prasarana air bersih

6. Belum efektifnya tata kelola lingkungan hidup yang baik sehingga kegiatan pembangunan tidak menimbulkan dampak berupa kerusakan lingkungan dan penurunan daya dukung/degradasi lingkungan.

\section{Tujuan Penelitian}

Tujuan penelitian ini adalah untuk menganalisis kebutuhan air bersih bagi masyarakat dan perusahaan/industri di wilayah Kecamatan Klari, Kecamatan Ciampel dan Kecamatan Purwasari.

\section{Manfaat Penelitian}

Manfaat penelitian ini adalah untuk mengkaji dan menganalisis kebutuhan air bersih bagi masyarakat dan perusahaan/industri di wilayah Kecamatan Klari, Kecamatan Ciampel dan Kecamatan Purwasari.

Hasil penelitian ini juga diharapkan dapat memberi manfaat bagi Pemerintah, PDAM maupun masyarakat pada umumnya. Bagi Pemerintah, penelitian ini diharapkan dapat menjadi bahan masukan dan rekomendasi terhadap penyediaan kebutuhan air bersih. Bagi PDAM, penelitian ini diharapkan dapat menjadi bahan masukan dalam meningkatkan pelayanan kepada masyarakat yang selama ini dinilai belum memuaskan. Bagi masyarakat dan perusahaan/industri, penelitian ini diharapkan dapat menjadi wacana dan bisa memberi kesempatan untuk mengungkapkan berbagai permasalahan yang dihadapi berkaitan dengan penyediaan kebutuhan air bersih, untuk dikaji lebih lanjut menuju kondisi yang lebih baik.

\section{Kajian Sistem Air Bersih}

Air bersih dalam kehidupan manusia merupakan salah satu kebutuhan paling esensial, sehingga kita perlu memenuhinya dalam jumlah dan kualitas yang memadai. Selain untuk dikonsumsi air bersih juga dapat dijadikan sebagai salah satu sarana dalam meningkatkan kesejahteraan hidup melalui upaya peningkatan derajat kesehatan (Sutrisno, 1991:1).

Tujuan utama sistem penyediaan air adalah untuk menyediakan air yang cukup berlebihan, yaitu untuk menyediakan air bersih ke tempat-tempat yang dikehendaki dengan tekanan yang cukup. Tetapi pada masa kini ada pembatasan dalam jumlah air yang dapat 
diperoleh karena pertimbangan penghematan energi dan adanya keterbatasan sumber air (Noerbambang, 1993:3).

Dalam tinjauan aspek teknis, penyediaan air bersih dapat dibedakan dua sistem (Chatib, 1996:25), yaitu:

1. Sistem penyediaan air bersih individual (Individual Water Supply System).

Sistem penyediaan air bersih individual adalah sistem penyediaan air bersih untuk penggunaan individual atau pelayanan terbatas. Sumber air yang digunakan dalam sistem ini umumnya berasal dari air tanah. Hal ini disebabkan air tanah memiliki kualitas yang relatif baik dibanding sumber lainnya. Sistem penyediaan ini biasanya tidak memiliki komponen transmisi dan distribusi. Kecuali pada penyediaan air bersih yang dibangun oleh pengembang untuk melayani suatu lingkungan perumahan yang dibangunnya.

2. Sistem penyediaan air bersih komunitas (Community/Municipality Water Supply System).

Sistem penyediaan air bersih komunitas atau perkotaan adalah suatu sistem penyediaan air bersih untuk masyarakat umum atau skala kota, dan untuk pelayanan yang menyeluruh, termasuk untuk keperluan rumah tangga (domestik), sosial maupun industri. Pada umumnya sistem ini merupakan sistem yang lengkap dan menyeluruh bahkan kompleks, baik dilihat dari teknis maupun sifat pelayanannya.

Kesulitan dalam penyediaan infrastruktur sudah mulai berlangsung sejak lama. Persoalan-persoalan yang ada antara lain meliputi : keterbatasan dana dari pemerintah, peningkatan penduduk yang terus berlangsung terutama di kota-kota besar, euforia otonomi yang cenderung kebablasan dari Kabupaten/Kota menjadi beberapa penyebab perkembangan infrastruktur kalah cepat dibandingkan dengan dinamika pertumbuhan yang ada. Pelayanan air bersih belum menyentuh seluruh lapisan masyarakat yang membutuhkan baik di kota maupun di desa (Kodoatie, 2003:1).

Sistem infrastruktur merupakan pendukung utama fungsi-fungsi sistem sosial dan sistem ekonomi dalam kehidupan sehari-hari masyarakat. Sistem infrastruktur dapat didefinisikan sebagai fasilitas-fasilitas atau struktur-struktur dasar, peralatan-peralatan, instalasi-instalasi yang dibangun dan yang dibutuhkan untuk berfungsinya sistem sosial dan sistem ekonomi masyarakat (Grigg dalam Kodoatie, 2003:9).

Penanganan infrastruktur sektor air bersih pada prinsipnya diutamakan bagi masyarakat yang belum memiliki akses terhadap air bersih, terutama pada daerah-daerah rawan air, permukiman kumuh, nelayan dan daerah tertinggal (Kodoatie,2003:151-152).

Berdasarkan standar yang ditetapkan oleh Departemen Pekerjaan Umum, kebutuhan air bersih untuk masing-masing rumah tangga untuk Kota Kecil dengan jumlah penduduk antara 20.000 - 100.000 jiwa adalah 100-130 liter/orang per hari. Berikut ini adalah Tabel perkiraan air bersih berdasarkan jumlah penduduk (kategori kota) untuk kebutuhan domestik menurut standar yang ditetapkan oleh Departemen Pekerjaan Umum

Tabel 2

Kebutuhan Air Bersih Untuk Domestik

Berdasarkan Kategori Kota

\begin{tabular}{|c|c|c|}
\hline Kategori Kota & $\begin{array}{c}\text { Jumlah Penduduk } \\
\text { (jiwa) }\end{array}$ & $\begin{array}{c}\text { Kebutuhan air } \\
\text { (liter/orang/hari) }\end{array}$ \\
\hline
\end{tabular}




\begin{tabular}{|c|c|c|}
\hline Metropolitan & $>1.000 .000$ & $170-190$ \\
Kota Besar Kota Sedang & $500.000-1.000 .000$ & $150-170$ \\
Kota Kecil & $100.000-500.000$ & $130-150$ \\
Ibukota Kecamatan & $20.000-100.000$ & $100-130$ \\
\hline
\end{tabular}

Sumber : Departemen Pekerjaan Umum, 1995

Peranan air bersih dalam kehidupan masyarakat begitu penting, karena selain menjadi bahan konsumsi yang dibutuhkan untuk minum dan memasak, air juga dapat menjadi media di dalam menimbulkan berbagai gangguan kesehatan, karena air mempunyai kemampuan yang tinggi dalam melarutkan bahan-bahan padat, mengabsorpsi gas-gas dan bahan cair lainnya, sehingga kandungan bahan atau zat-zat ini dalam air pada konsentrasi tertentu dapat menimbulkan efek gangguan kesehatan bagi pemakainya.

Disamping itu air juga merupakan media yang efektif di dalam penyebaran penyakit (water born decease), terutama untuk penyakit-penyakit yang berhubungan dengan penyakit infeksi bakteri pada usus seperti : typus, paratypus, dysentri, bacilair dan kolera (Sutrisno, 1991:24).

Oleh karena itu untuk menghindari hal-hal yang tidak diinginkan berkaitan dengan penggunaan air bersih maka telah ditetapkan berbagai standar kualitas air bersih yang dapat dijadikan sebagai acuan dalam menentukan apakah air bersih yang akan dipergunakan telah memenuhi persyaratan kesehatan atau belum.

\section{Prinsip Manajemen dalam Pengelolaan Air Bersih}

Dalam kegiatan layanan air bersih, perlu memperhatikan prinsip-prinsip manajemen, karena dalam menjalankan organisasi dibutuhkan manajemen/ pengelolaan. Manajemen/pengelolaan sumberdaya air didefinisikan sebagai aplikasi dari cara struktural dan non-struktural untuk mengendalikan sistem sumberdaya air alam dan buatan manusia untuk kepentingan/manfaat manusia dan tujuan-tujuan lingkungan (Grigg dalam Kodoatie, 2005:193).

Dalam pengelolaan layanan air bersih, terdapat tiga aspek yang harus diperhatikan yaitu aspek pemanfaatan, aspek pelestarian/konservasi, dan aspek pengendalian (Kodoatie, et.al, 2002:29). Dalam memanfaatkan air bersih, perlu disertai dengan upaya pelestarian/ konservasi, agar pemanfaatannya bisa berkelanjutan. Konservasi dalam hal ini tidak hanya diartikan sebagai kegiatan menyimpan air saja atau disebut sebagai konservasi dari segi suplai, tetapi lebih mengarah kepada pengurangan atau pengefisienan penggunaan air yang sering disebut sebagai konservasi dari segi kebutuhan. Konservasi air yang baik merupakan gabungan dari kedua konsep tersebut, yaitu menyimpan air di kala berlebihan, menggunakannya sesedikit mungkin untuk keperluan tertentu yang produktif. Sehingga konservasi air domestik berarti menggunakan air sesedikit mungkin untuk mandi, mencuci, menggelontor toilet, dan penggunaan- penggunaan rumah tangga lainnya (Suripin, 2002:133).

\section{Kerangka Pemikiran}

Kerangka pikir dalam studi ini didasarkan pada ketersediaan air bersih di Kabupaten Karawang, padahal kebutuhan air bersih untuk penduduk dan aktivitas perusahaan semakin meningkat. Sedangkan pelayanan PDAM belum dapat memenuhi kebutuhan dasar air sepanjang tahun. Untuk itu masyarakat menempuh cara melakukan penyediaan air bersih dengan memanfaatkan air tanah. Fenomena ini terjadi di beberapa permukiman di Kabupaten Karawang.

Langkah-langkah dalam mencapai tujuan tersebut adalah sebagai berikut : 
- Identifikasi dan analisis karakteristik masyarakat dan industri.

- Identifikasi dan analisis persepsi masyarakat dan perusahaan/industri terhadap penyediaan kebutuhan air bersih.

- Kajian aspek-aspek yang mempengaruhi penyediaan kebutuhan bersih dan kontinuitas penyediaan air bersih.

Identifikasi dan analisis karakteristik dilakukan dengan distribusi frekuensi, identifikasi dan analisis persepsi terhadap penyediaan air bersih dengan menggunakan metode analisis deskriptif kuantitatif dengan tabel distribusi frekuensi dan metode tabulasi silang.

Selanjutnya identifikasi analisis aspek-aspek yang mempengaruhi penyediaan air bersih dan kontinuitas penyediaan air bersih menggunakan metode analisis deskriptif kuantitatif dengan tabel distribusi frekuensi. Output dari studi ini adalah aspek-aspek yang mempengaruhi penyediaan air bersih dan kontinuitas penyediaan air bersih berikut alternatif pengendalian penyediaan air bersih kemudian dilanjutkan kesimpulan serta rekomendasi. Berdasarkan uraian tersebut diatas, berikut merupakan diagram kerangka pikir dalam kajian aspek-aspek yang mempengaruhi penyediaan air bersih.

\section{Metode Penelitian}

Penelitian ini merupakan jenis penelitian survei yang mengambil sampel warga masyarakat Kecamatan Klari, Kecamatan Purwasari dan Kecamatan Ciampel di Kabupaten Karawang yang dilaksanakan dengan cara mengambil sampel dari satu populasi dan menggunakan kuesioner sebagai alat pengumpulan data pokok.

Kajian aspek-aspek penyediaan air bersih, dilakukan dengan fokus penelitian pada kenyataan yang terjadi di lapangan. Permasalahan yang terjadi adalah belum optimalnya penyediaan air bersih yang digunakan dan ketersediaan air bersih yang terbatas. Untuk itu diperlukan suatu kajian tentang penyediaan air bersih dan penyediaan air bersih oleh PDAM atau perusahaan lain berdasarkan persepsi masyarakat. Kemudian dilanjutkan kajian aspek-aspek yang mempengaruhi penyediaan air bersih.

Dalam studi ini terlebih dahulu dilakukan identifikasi karakteristik masyarakat, identifikasi persepsi penghuni terhadap penyediaan air bersih dan oleh PDAM berdasarkan karakteristiknya. Kemudian dilanjutkan identifikasi aspek-aspek yang mempengaruhi penyediaan air bersih berdasar aspek-aspek yang berhubungan.

Selanjutnya dilakukan analisis karakteristik penghuni warga masyarakat dan perusahaan/industri. Metode analisis yang digunakan adalah metode analisis deskriptif kuantitatif dengan menggunakan tabel distribusi frekuensi. Selanjutnya analisis persepsi penghuni terhadap penyediaan air bersih. Metode analisis yang digunakan adalah metoda analisis deskriptif kuantitatif dengan menggunakan tabel distribusi frekuensi dan tabulasi silang. Berikutnya analisis aspek-aspek yang mempengaruhi penyediaan air bersih dan kontinuitas penyediaan air bersih menggunakan metode analisis deskriptif kuantitatif dengan menggunakan tabel distribusi frekuensi. Hasil penelitian/studi berupa aspek-aspek yang mempengaruhi penyediaan air bersih dan kontinuitas penyediaan air bersih berikut alternatif pengendalian penyediaan air bersih.

\section{Teknik Pengumpulan dan Pengolahan Data}

Pada suatu proses penelitian, tahapan pengumpulan data merupakan tahapan yang harus direncanakan secara optimal yang sesuai dengan tujuan dan sasaran penelitian. Pengumpulan data yang dilakukan dalam studi ini meliputi pengumpulan data primer dan pengumpulan data sekunder.

1. Pengumpulan Data Primer 
Data primer dikumpulkan melalui survei primer yang dilakukan melalui pengamatan langsung (observasi) di lapangan dan penyebaran kuesioner atau pertanyaan kepada para masyarakat dan industri yang mengetahui aspek yang ditanyakan. Teknik pengumpulan data primer adalah sebagai berikut :

\section{a. Pengamatan visual}

Pengamatan ini dilakukan dengan observasi lapangan untuk melihat kondisi eksisting lingkungan masyarakat.

\section{b. Kuesioner}

Teknik pengumpulan data ini dilakukan untuk memperoleh informasi mengenai persepsi penghuni terhadap penyediaan air bersih. Kuesioner disebarkan kepada masyarakat dan perwakilan perusahaan/industri.

2. Pengumpulan Data Sekunder

Data sekunder merupakan data yang berasal dari instansi terkait dengan studi untuk mendapatkan data-data yang dibutuhkan untuk kegiatan analisis. Disamping itu, data sekunder lainnya adalah studi literatur untuk mendapatkan literatur yang berkaitan dengan studi.

Pengumpulan data dilakukan melalui survei ke beberapa Instansi yang diharapkan dapat menjadi sumber data, yaitu :

a. Bappeda Kabupaten Karawang

c. BPS Kabupaten Karawang

e. PDAM Tirta Tarum Karawang

Dalam pengolahan data, untuk memperkaya data dan lebih memahami fenomena sosial yang diteliti dilengkapi pula dengan data sekunder, dan dari kedua data yang diperoleh dilakukan analisis melalui pendekatan kuantitatif dan kualitatif. Pendekatan kuantitatif dilakukan melalui perhitungan statistik dari data yang diperoleh dari responden melalui jawaban kuesioner (terlampir) dengan perangkat keras personal komputer dan perangkat lunak SPSS versi 13.00. Sedangkan pendekatan kualitatif dilakukan melalui analisis data dari pengamatan lapangan dan lain-lain yang diperoleh dari instansi terkait.

\section{Teknik Sampling}

Dalam menentukan teknik pengambilan sampel yang akan digunakan dalam suatu penelitian, ada tiga hal yang harus diperhatikan yaitu tenaga, biaya dan waktu. Populasi penelitian adalah penduduk di Kecamatan Ciampel, Kecamatan Purwasari dan Kecamatan Klari Kabupaten Karawang. Semua masyarakat dan perusahaan/industrimempunyai kesempatan yang sama untuk menjadi responden dalam penelitian.

Untuk pengambilan sejumlah sampel menurut Kartono (1992:82), pada prinsipnya tidak ada peraturan yang ketat secara mutlak menentukan berapa persen sampel tersebut harus diambil dari suatu populasi. Dalam penelitian, sampel yang akan diambil adalah warga masyarakat dari Kecamatan Ciampel. Kecamatan Purwasari dan Kecamatan Klari sebanyak 400 orang dan sampel dari perusahaan/industri sebanyak 100 orang.

Menurut Arikunto (1997:108), apabila seseorang ingin meneliti semua elemen yang ada dalam wilayah penelitian, maka penelitiannya merupakan penelitian populasi. Obyek pada populasi diteliti, hasilnya dianalisis, disimpulkan dan kesimpulan itu berlaku untuk seluruh populasi. Distribusi sampel dalam kajian penyediaan air bersih untuk selengkapnya dapat dilihat pada tabel di bawah ini.

Tabel 3

Distribusi Sampel

\begin{tabular}{|c|c|c|}
\hline No & Kecamatan & Jumlah Sampel \\
\hline 1 & Ciampel & 132 \\
\hline
\end{tabular}




\begin{tabular}{|l|l|c|}
\hline 2 & Purwasari & 111 \\
\hline 3 & Klari & 157 \\
\hline 4 & Perusahaan/industri & 100 \\
\hline & Total & 500 \\
\hline
\end{tabular}

Sumber : Peneliti, 2018.

\section{Metode dan Teknik Analisis}

Metode analisis ini menjelaskan mengenai prinsip dasar analisis yang akan digunakan. Metode analisis yang digunakan dalam studi ini adalah :

1. Analisis karakteristik warga masyarakat

Analisis ini digunakan untuk mengetahui gambaran sosial ekonomi penghuni yang dimungkinkan berpengaruh pada persepsi masyarakat dan perusahaan terhadap penyediaan air bersih. Karakteristik yang akan dibahas disini meliputi : status domisili, lama tinggal, pekerjaan, pendapatan, pendidikan dan jumlah penghuni. Metode analisis yang digunakan dalam analisis ini adalah analisis deskriptif kuantitatif dengan menggunakan tabel distribusi frekuensi.

2. Analisis persepsi terhadap penyediaan air bersih penyediaan air bersih oleh PDAM berdasarkan karakteristik penghuni

Analisis ini digunakan untuk mengetahui persepsi penghuni terhadap penyediaan air bersih. Metode analisis yang digunakan adalah analisis deskriptif kuantitatif dengan menggunakan alat metode tabel distribusi frekuensi dan tabulasi silang. Analisis deskriptif kuantitatif ini digunakan untuk menggambarkan persepsi terhadap penyediaan air bersih.

Selain itu metode analisis yang digunakan adalah analisis kuantitatif deskriptif dengan menggunakan Metode Cross Tabs (Metode Tabulasi Silang). Metode Tabulasi Silang adalah suatu metode untuk mentabulasikan beberapa variabel yang berbeda ke dalam suatu matriks. Hasil tabulasi silang disajikan ke dalam suatu variabel-variabel yang tersusun sebagai kolom dan baris tabel tersebut. Dengan analisis ini dapat digunakan untuk pengecekan silang antar beberapa variabel sehingga diketahui tingkat keterhubungan antar variabel yang dibandingkan.

Tabel 4

Variabel dalam Analisis Tabulasi Silang

\begin{tabular}{|l|l|}
\hline \multicolumn{1}{|c|}{ Variabel Terikat } & \multicolumn{1}{|c|}{ Variabel Bebas } \\
\hline Persepsi masyarakat dan & Karakteristik Penghuni : \\
perusahan/industri dalam & - Lama tinggal \\
penyediaan kebutuhan air bersih & - Pekerjaan \\
& - Pendapatan \\
& - Pendidikan \\
& - Jumlah penghuni rumah \\
& - Lama tinggal \\
& - Pekerjaan \\
& - Pendapatan \\
& - Pendidikan \\
\hline
\end{tabular}


Sumber : Analisis peneliti, 2018.

3. Analisis aspek-aspek yang mempengaruhi penyediaan air bersih dan kontinuitas penyediaan air bersih.

Analisis ini digunakan untuk mengetahui aspek-aspek yang paling mempengaruhi penyediaan air bersih untuk mengetahui kontinuitas penyediaan air bersih ditinjau dari pemakaian air bersih, pola pemakaian air bersih dan ketersediaan air bersih. Metode analisis yang digunakan adalah analisis deskriptif kuantitatif dengan tabel distribusi frekuensi. Kemudian dilanjutkan rekomendasi tentang alternatif penyediaan kebutuhan air bersih.

\section{Hasil Penelitian dan Pembahasan}

Penyediaan air bersih merupakan gagasan yang berasal dari warga ketika pertama/awal menempati rumah atau kawasan. Pada waktu itu PDAM belum mempunyai jaringan yang luas untuk menjangkau saluran. Sejak awal di beberapa kawasan belum dilengkapi dengan jaringan primer dan sekunder prasarana lingkungan termasuk air bersih. Pembangunan rumah juga di dilakukan sendiri oleh penghuni. Tidak seperti kawasan siap bangun dan lingkungan siap bangun lainnya yang sudah dilengkapi jaringan prasarana lingkungan. Dengan demikian penghuni dan warga cenderung memilih penyediaan air bersih untuk memenuhi kebutuhan air bersih sehari-hari dengan cara yang berbeda-beda.

Dan ternyata beberapa suember air bersih diantaranya air sumur, sumur bor, penampungan air hujan, jaringan PDAM yang dimanfaatkan oleh penghuni secara kuantitas belum optimal. Gagasan penyediaan air bersih dari sumber lain yang berbayar ternyata mampu meyakinkan warga masyarakat dan perusahaan/industri. Bahkan sampai sekarang beberapa warga masyarakat dan perusahaan/industri menggunakan air bersih dari sumbersumber lain selain PDAM.

Adapun temuan kajian penelitian dari hasil analisis yang telah dilakukan adalah sebagai berikut :

Tabel 5

Cross Tabb Kesediaan Berlangganan Air Bersih selain PDAM

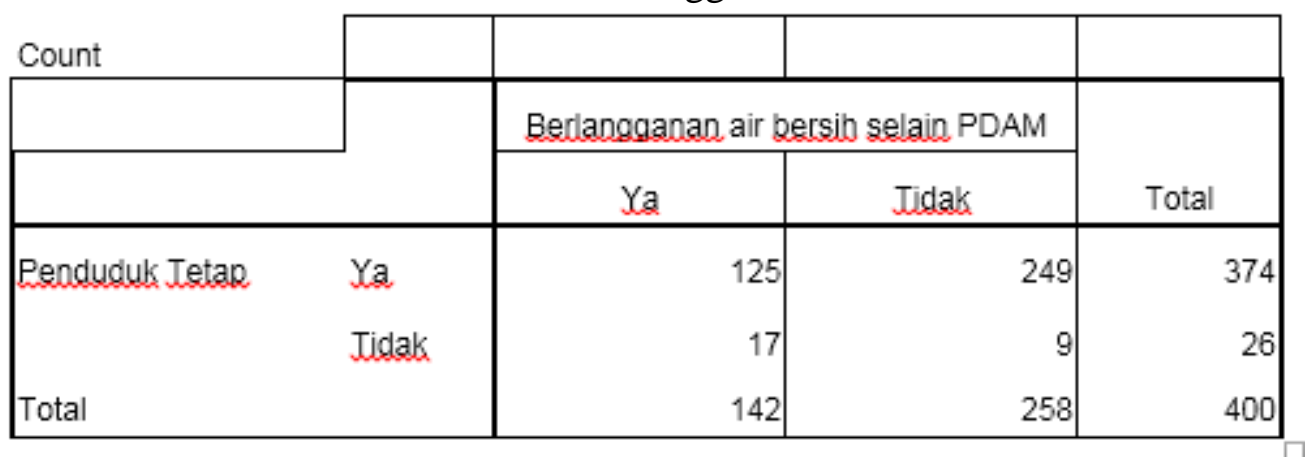

Sumber : Hasil olah kuesioner, SPSS, 2018.

Bahwa sebanyak 142 orang atau sebesar $36 \%$ warga masyarakat bersedia berlangganan air bersih selain PDAM dan sisanya sebanyak 258 orang atau sebesar $64 \%$ tidak bersedia berlangganan air bersih selain PDAM.

Tabel 6

Cross Tabb Kesediaan Berlangganan Air Bersih selain PDAM 


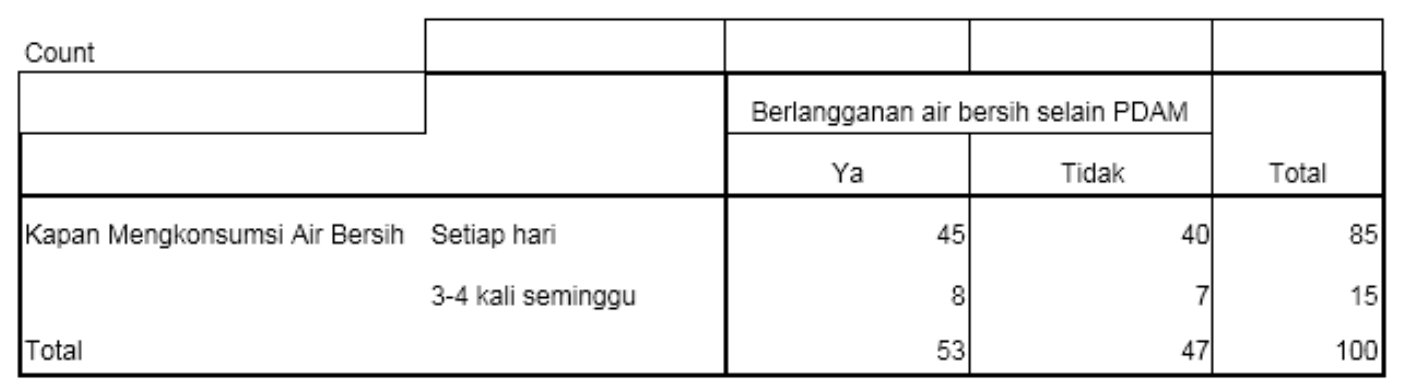

Sumber : Hasil olah kuesioner, SPSS, 2018.

Bahwa sebanyak 53 perusahaan/industri atau sebesar $53 \%$ bersedia berlangganan air bersih selain PDAM dan sisanya sebanyak 47 orang atau sebesar $47 \%$ tidak bersedia berlangganan air bersih selain PDAM.

Tabel 7

Cross Tabb Kendala Pemenuhan Kebutuhan Air Bersih Masyarakat

\begin{tabular}{|c|c|c|c|c|}
\hline \multicolumn{5}{|l|}{ Count } \\
\hline & & \multicolumn{2}{|c|}{ Berlangganan air bersib selain PDAM } & \multirow[b]{2}{*}{ Total } \\
\hline & & Ya & Jidak & \\
\hline \multirow{4}{*}{$\begin{array}{l}\text { Kendala Remenuhan Kebutuhaan } \\
\text { Air Bersing }\end{array}$} & Biava mahal & 50 & 135 & 185 \\
\hline & Kualitas air tidak baik & 50 & 60 & 110 \\
\hline & $\begin{array}{l}\text { Jidak tersedianva jaringan air } \\
\text { bersin }\end{array}$ & 20 & 35 & 55 \\
\hline & Jidak tersedianva jaringan PDAM & 22 & 28 & 50 \\
\hline Total & & 142 & 258 & 400 \\
\hline
\end{tabular}

Sumber : Hasil olah kuesioner, SPSS, 2018.

Kendala pemenuhan kebutuhan air bersih bagi warga masyarakat sebanyak 185 orang atau $46 \%$ menyatakan berbiaya mahal, sebanyak 110 warga masyarakat atau $28 \%$ karena kualitas air tidak baik, sebanyak 55 warga masyarakat atau $14 \%$ karena tidak tersedianya jaringan air bersih dan sebanyak 50 orang atau 13\% karena tidak tersedianya jaringan PDAM di wilayah tersebut.

\section{Tabel 8}

Cross Tabb Kendala Pemenuhan Kebutuhan Air Bersih Perusahaan/Industri 
E ISSN : 2580-5517

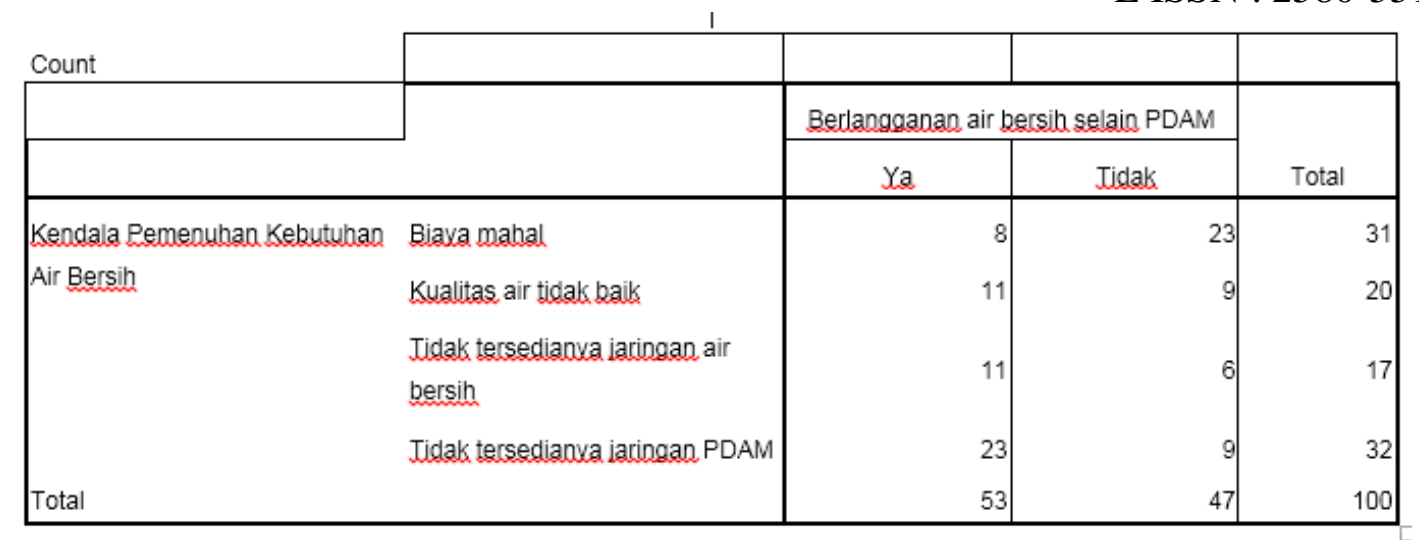

Sumber : Hasil olah kuesioner, SPSS, 2018.

Kendala pemenuhan kebutuhan air bersih bagi perusahaan/industri sebanyak 31 perusahaan/induutri atau $31 \%$ menyatakan berbiaya mahal, sebanyak 20 perusahaan/industri atau 20\% karena kualitas air tidak baik, sebanyak 17 perusahaan/industri atau $17 \%$ karena tidak tersedianya jaringan air bersih dan sebanyak 32 perusahaan/industri atau $32 \%$ karena tidak tersedianya jaringan PDAM di wilayah tersebut.

Persepsi warga dan perusahaan/industri sebagian besar memiliki karakteristik yang homogen, yaitu: pendapatan, pekerjaan, lama menempati rumah. Persepsi warga dan perusahaan/industri terhadap penyediaan air bersih adalah sebagai berikut:

a. secara teknik operasional, PDAM belum mampu menyediakan air bersih yang layak secara kualitas, kuantitas maupun kontinuitas. Sumber air yang ada tersebar, belum terukur dengan debit relatif kecil.

b. secara kelembagaan, kinerja dan tingkat pelayanan PDAM belum memuaskan pelanggan. PDAM belum memiliki manajemen yang cukup baik untuk melayani masyarakat.

c. secara peran serta masyarakat, hanya sebatas pengaduan bila terjadi pelanggaran di lapangan maupun kebocoran pipa.

d. aspek yang paling mempengaruhi penyediaan air bersih adalah aspek teknik operasional karena tidak memerlukan teknologi tinggi dan cara pembuatan maupun pemeliharaan relatif mudah dilakukan. Sedangkan kontinuitas penyediaan air bersih sampai saat ini belum cukup memenuhi kebutuhan air bersih masyarakat dan perusahaan/industri. Sehingga penyediaan air bersih dengan alternatif lain dapat menjadi salah satu pilihan untuk memenuhi kebutuhan air bersih.

\section{Simpulan}

Berdasarkan hasil penelitian dan kajian yang telah dikemukakan di atas, dapat diberikan kesimpulan sebagai berikut :

1. Karakteristik warga masyarakat memiliki tingkat sosial ekonomi yang cukup tinggi dan relatif homogen. Kondisi sosial ekonomi ini berpengaruh terhadap tuntutan ketersediaan air bersih yang layak. Sedangkan karakteristik perusahaan/industri sangat heterogen namun juga mempunyai tuntutan yang sama terhadap pemenuhan kebutuhan air bersih.

2. Persepsi warga masyarakat terhadap penyediaan air bersih pada umumnya sama mempunyai penilaian yang kurang baik baik terhadap penyediaan air bersih oleh PDAM. Persepsi wrga masyarakat dan perusahaan/industri terhadap penyediaan air bersih tidak dipengaruhi oleh karakteristik warga masyarakat dan perusahaan/industri karena mempunyai persepsi yang cenderung sama. 
3. Pemilihan penyediaan air bersih ternyata dibutuhkan teknologi yang tidak terlalu rumit sehingga operasional dan pemeliharaan relatif mudah dilakukan, murah dan terjangkau dan secara partisipasi masyarakat terhadap kebutuhan air bersih memiliki kebersamaan yang tinggi.

4. Warga masyarakat dan perusahaan/industri banyak yang tidak bersedia berlangganan PDAM karena tidak memenuhi kebutuhan air bersih baik secara kualitas, kuantitas maupun kuantitas hal ini juga disebabkan oleh kinerja dan tingkat pelayanan belum memuaskan, sehingga diperlukan alternatif lain dalam penyediaan air bersih.

5. Secara keseluruhan dilihat dari berbagai aspek, penyediaan air bersih pada saat ini belum cukup memenuhi kebutuhan secara optimal. Dengan demikian penyediaan air bersih melalui perusahaan lain selain PDAM dapat menjadi salah satu alternatif untuk memenuhi kebutuhan air bersih. Semakin padatnya warga masyarakat dan perusahaan/industri, maka akan dihadapkan pada masalah penyediaan air bersih yang semakin besar. Sarana air bersih yang minim dengan sumber daya air yang semakin terbatas menjadi satu kendala yang sangat berarti. Semakin bertambah jumlah warga masyarakat dan perusahaan/industri maka akan semakin bertambah banyak sehingga kebutuhan air bersih juga semakin bertambah. Dengan demikian penyediaan air bersih dari sumber-sumber lain juga sangat diperlukan.

\section{Rekomendasi}

Adapun rekomendasi atau arahan yang diusulkan agar penyediaan air bersih dapat dilakukan secara terkendali, terjamin kontinuitasnya dan agar tidak mengakibatkan kerusakan lingkungan serta alternatif penyediaan air bersih jangk panjang adalah:

1. Bagi Pemerintah Kabupaten Karawang

a. Melakukan pengawasan dan pengendalian terhadap pemanfaatan sumber air.

b. Mengupayakan penyediaan air bersih dengan sistem jaringan maupun sistem lainnya yang lebih terjangkau harganya dan kualitas yang baik.

a. Perlu meningkatkan pelayanan terutama dalam hal menjamin kualitas, kuantitas dan kontinuitas sesuai standar yang berlaku serta menambah kapasitas air bersih terpasang. PDAM semestinya punya pertimbangan untuk memberikan pelayanan yang mengutamakan supply kepada masyarakat.

d. Sumber daya air dapat dijadikan alternatif untuk mengembangkan cakupan pelayanan di kawasan permukiman dan kawasan industri lainnya dengan sistem komunal/distribusi terpusat.

2. Bagi masyarakat

a. Partisipasi masyarakat dalam membantu mewujudkan terciptanya pembangunan sistem penyediaan air bersih publik yang lebih baik dan luas.

b. Masyarakat hendaknya perlu upaya untuk bisa mendapatkan pelayanan air bersih dengan sistem jaringan air bersih oleh sumber lain selain PDAM maupun sistem lainnya agar tidak terjadi eksploitasi terhadap air tanah yang akan menurunkan kualitas lingkungan. Sesuai dengan kondisi masyarakat dan perusahaan/industri, secara keseluruhan menggunakan air bersih dari sumber yang bervariasi, maka jawaban yang diperoleh tentang persepsi terhadap penyediaan air bersih, sebagian besar adalah pendapat yang tidak didasarkan pengalaman namun berdasarkan perkiraan karena seluruh warga dan perusahaan/industri belum pernah ada yang berlangganan selain PDAM.

3. Bagi perusahaan/industri 
Perlunya melakukan kerjasama dan kemitraan strategis guna membuat master plan yang menyeluruh untuk penyediaan air bersih mengingat teknologi, pembiayaan dan potensi kebutuhan air bersih yang sangat besar.

\section{Daftar Pustaka}

\section{Buku}

Kodoatie, Robert J., dkk (eds).2001.Pengelolaan Sumber Daya Air dalam Otonomi Daerah.Yogyakarta : Penerbit Andi

Kodoatie, Robert J. 2003.Pengantar Manajemen Infrastruktur.Yogyakarta. Penerbit : Pustaka Pelajar

2003. Manajemen dan Rekayasa Infrastruktur. Yogyakarta. Penerbit

: Pustaka Pelajar 2005. Pengelolaan Sumber Daya Air Terpadu. Yogyakarta. Penerbit : Andi

Kodoatie, Robert J., Basoeki. 2005. Kajian Undang-Undang Sumber Daya Air. Yogyakarta. Penerbit : Andi

Suripin.2004. Pelestarian Sumber Daya Tanah dan Air. Yogyakarta. Penerbit : Andi

Tjahjati, B. et. al, 2005. Konsep dan Pendekatan Pembangunan Perkotaan di Indonesia, Bunga Rampai Pembangunan Kota Indonesia Dalam Abad 21. Jakarta. Yayasan Sugijanto Soegijoko

\section{Peraturan}

Undang-Undang Sumber Daya Air Republik Indonesia Nomor 7 Tahun 2004 tentang Sumber Daya Air dan Penjelasannya

Undang-Undang Nomor 8 Tahun 1999 tentang Perlindungan Konsumen

Peraturan Pemerintah Nomor 80 Tahun 1999 tentang Kawasan Siap Bangun dan Lingkungan Siap Bangun yang Berdiri Sendiri

Keputusan Menteri Energi dan Sumberdaya Mineral Nomor 1451 K/10/MEM/2000 tentang Pedoman Teknis Penyelenggaraan Tugas Pemerintahan di Bidang Pengelolaan Air Bawah Tanah Tahun 2000

Ketentuan Umum Permenkes Nomor 416/Menkes/PER/IX/1990 tentang Persyaratan Air Bersih

Peraturan Pemerintah Republik Indonesia Nomor 16 Tahun 2005 tentang Pengembangan Sistem Penyediaan Air Minum

\section{Buku Data/Laporan}

Kebijakan Nasional Penyelenggaraan Air Minum dan Penyehatan Lingkungan Berbasis Lembaga, Konsep Ketiga (Revisi Kedua), Bappenas Tahun 2005

Rencana Pembangunan Jangka Menengah (RPJM) Kabupaten Karawang Tahun 2018 $-2021$ 